\title{
Calcium Nitrate Dose and Application Period in American Lettuce (Lactuca sativa L.)
}

\author{
Cleiton Gredson Sabin Benett ${ }^{1}$, Alan Kênio dos Santos Pereira ${ }^{1}$, Leandro Caixeta Salomão ${ }^{2}$, \\ Katiane Santiago Silva Benett ${ }^{1} \&$ Natalia Arruda $^{1}$ \\ ${ }^{1}$ Department of Agronomy, State University of Goiás, Campus Ipameri, Ipameri, Goias, Brazil \\ ${ }^{2}$ Federal Institute Goiás, Campus Urutaí, Urutaí, Goias, Brazil \\ Correspondence: Cleiton Gredson Sabin Benett, Department of Agronomy, State University of Goiás, Campus \\ Ipameri, Ipameri, Goias, Brazil. Tel: 55-(64)-3491-1556. E-mail: cleiton.benett@gmail.com
}

Received: March 7, 2018

doi:10.5539/jas.v10n6p154

\author{
Accepted: Arpil 8, 2018 \\ Online Published: May 15, 2018 \\ URL: https://doi.org/10.5539/jas.v10n6p154
}

\begin{abstract}
The aim of this study was to evaluate the yield of American lettuce subjected to different dosages of calcium nitrate on two application schedules. The experiment used four replicates of a $2 \times 5$ factorial randomized complete block design, with two application schedules (Schedule 1: 50\% of the dose at transplanting and 50\% at 20 days after transplanting; Schedule 2: 50\% at 10 days and $50 \%$ at 20 days after transplanting) and five doses (0, $150,300,450$ and $\left.600 \mathrm{~kg} \mathrm{ha}^{-1}\right)$. The following variables were evaluated: the number of inner and outer leaves, head height and diameter, head height/diameter ratio, compactness, stem diameter, relative index of chlorophyll, commercial production and nitrogen $(\mathrm{N})$ and calcium $(\mathrm{Ca})$ content in the inner and outer leaf. The data were subjected to analysis of variance ( $\mathrm{F}$ test, with Tukey test for comparison of the means) for the application schedule and regression analysis for the calcium nitrate dose. The application of calcium nitrate positively influenced the nutritional characteristics of American lettuce in the $2^{\text {nd }}$ schedule and the dose of $470 \mathrm{~kg} \mathrm{ha}^{-1}$ presented better production.
\end{abstract}

Keywords: fertilization, production, calcium, nitrogen

\section{Introduction}

Lettuce (Lactuca sativa L.), among the leafy vegetables, is the most commercialized in Brazil. It has a high content of vitamins and has a large amount of minerals (Santi et al., 2013). It is consumed by all social classes and is even a raw material for some fast food centres. This vegetable has great social and economic importance and is cultivated by small and medium producers located near major cities.

Commercial cultivars are categorized by their leaf characteristics and whether they form a cabbage-like head. The American type presents characteristically crisp, consistent leaves with prominent ribs, forming a compact head. It is highly resistant to transport and recommended for the preparation of sandwiches, since it resists contact with hot foods better than other cultivars (Filgueira, 2013).

A balanced mineral fertilization is necessary for commercial crops, and potassium $(\mathrm{K})$, nitrogen $(\mathrm{N})$, calcium $(\mathrm{Ca})$ and phosphorus $(\mathrm{P})$ are the most absorbed elements in lettuce fertilization. Lettuce has high demand for $\mathrm{N}$, and $\mathrm{N}$ deficiency slows plant growth and induces poor head formation and yellowing of older leaves (Olfati et al., 2009). When $\mathrm{Ca}$ is not available at appropriate levels, a physiological disturbance called 'tip burn' may occur, which is more pronounced in hot regions (Beninni et al., 2003; Cometti et al., 2004).

Soil characteristics, fertilizer application timing, climatic conditions and soil management practices are mentioned as some of the factors influencing plant nutrient dynamics (Santos et al., 2010a). N is a nutrient that requires adequate management in the lettuce crop because it easily leaches from the soil and because the crop absorbs a larger amount of $\mathrm{N}$ in the final stage of the cycle. According to Costa et al. (2010), two aspects are fundamental to the management of $\mathrm{N}$ fertilization: the source and the parcelling of the doses to reduce losses by volatilization and leaching.

Among the various sources of $\mathrm{N}$ available, calcium nitrate is advantageous because it has shown satisfactory results in various crops. Zanão Júnior et al. (2005) found that calcium nitrate promoted better production than urea in Malaysian cabbage (Brassica chinensis L.). Cardoso and Hiraki (2001) observed an increase in radish 
(Raphanus sativus L.) root production. Martínez et al. (2013) concluded that calcium nitrate provided a higher yield of tomato (Lycopersicum esculentum) fruits. Cortez et al. (2009) concluded that increased calcium nitrate doses provided better results in lettuce production. Other studies point to improved lettuce production when calcium nitrate is used to supply the $\mathrm{N}$ and $\mathrm{Ca}$ (Chohura \& Kolota, 2011).

In this context, the aim of this study was to evaluate the productivity of the American lettuce fertilized with calcium nitrate in different doses and in two application schedules.

\section{Material and Methods}

\subsection{Location and Installation of the Experiments}

The experiment was carried out in an open field from March to June 2014 in the municipality of Catalão, Goias state (GO), at $18^{\circ} 09^{\prime} 49.6^{\prime \prime} \mathrm{S}, 47^{\circ} 18^{\prime} 56.4^{\prime \prime} \mathrm{W}$ and approximately 787 metres of altitude. The climate of the region, according to the Köppen-Geiger classification (Cardoso et al., 2014), is defined as tropical climate (Aw) with a dry season in winter.

The soil of the experimental area was classified as a dystrophic Red-Yellow Latosol with sand-clay texture (Santos et al., 2013). The chemical characteristics of the soil were evaluated in the 0 to $0.20-\mathrm{m}$ layer before the installation of the experiment following the methodology of Sousa and Lobato (2004), with the following values: $\mathrm{pH}\left(\mathrm{CaCl}_{2}\right)=6.2, \mathrm{P}=4 \mathrm{mg} \mathrm{dm}^{-3}, \mathrm{~K}=0.31 \mathrm{cmolc} \mathrm{dm}^{-3}, \mathrm{Ca}=1.84 \mathrm{cmolc} \mathrm{dm}^{-3}, \mathrm{Mg}=0.58 \mathrm{cmolc} \mathrm{dm}^{-3}, \mathrm{H}+\mathrm{Al}=$ $2.40 \mathrm{cmolc} \mathrm{dm}^{-3}$, cationic exchange capacity $(\mathrm{CEC})=5.12, \mathrm{~V}=53.3 \%$, and organic matter $(\mathrm{OM})=20.7 \mathrm{gm}^{3}$.

\subsection{Statistical Design and Plant Materials}

The experimental design was a randomized complete block factorial $2 \times 5$, two application schedules (Schedule 1: $50 \%$ of the dose at transplanting and $50 \%$ at 20 days after transplanting; Schedule 2: $50 \%$ at 10 days and $50 \%$ at 20 days after transplanting) and five doses $\left(0,150,300,450\right.$ and $\left.600 \mathrm{~kg} \mathrm{ha}^{-1}\right)$. The source of calcium nitrate used consisted of $14 \% \mathrm{~N}$ and $18 \% \mathrm{Ca}$.

The plots measured $1.0 \times 1.2 \mathrm{~m}$, containing four rows with four plants each, arranged in a spacing of $0.25 \times 0.30$ $\mathrm{m}$, totalling 16 plants per plot. The height of the beds was $20 \mathrm{~cm}$. For the evaluations, four central plants were used in each plot. The lettuce cultivar used was Lucy Brown, which has a 75-day cycle and is a large plant with thick leaves that protect the head. It is light green in colour and has good weight compactness and high tolerance to bolting.

The seedlings were produced in a protected nursery in expanded polystyrene trays with 200 cells. A commercial substrate was used for sowing, with two pelleted seeds being placed in each cell. After sowing, the seeds were covered with a thin layer of substrate, irrigated and taken to the nursery. Seedlings were thinned 10 days after emergence, leaving only one plant per cell. Watering in the nursery period was carried out three times per day by a micro sprinkler system. In the nursery phase, preventive treatment for pest and disease control and fertilization with monoammonium phosphate were carried out via irrigation.

The preparation of the experimental area consisted of ploughing, disking and manual turnover of the beds. Planting fertilization was carried out based on the soil analysis, according to the recommendation suggested by Filgueira (2013). At the time of planting 60,300 and $90 \mathrm{~kg} \mathrm{ha}^{-1}$ of $\mathrm{N}_{2} \mathrm{P}_{2} \mathrm{O}_{5}$ and $\mathrm{K}_{2} \mathrm{O}$, respectively, were applied. Transplanting was performed when the seedlings reached four leaves. Soon after transplanting, the area was irrigated. Irrigation management was carried out based on the daily evaporation rate, using a class A tank, with approximately $5 \mathrm{~mm} \mathrm{day}{ }^{-1}$ from a conventional sprinkler irrigation system. Crop treatments were performed as recommended for this crop.

\subsection{Evaluated Characteristics}

The harvest was performed when $80 \%$ of the plants in the experimental area were at harvest point to 51 days after transplanting; that is, when the plants had a completely closed head. The variables evaluated were height and head diameter, performed with the aid of a graduated ruler; stem diameter, determined by measuring with a digital calliper; head diameter $\times$ height ratio, determined by dividing the head height by the diameter, compactness, obtained by noting the scale of resistance (no head $=0$, soft $=1$, medium $=2$, firm $=3$ ) of the head to hand pressure, performed by the same person; the number of outer leaves after discarding the dead and senescent leaves, leaving only the heads of lettuce; relative index of chlorophyll, with readings being taken with a chlorophyll meter (ClorofiLog CFL 1030, Falker) on the mature leaves of four plants in each plot; number of outer and inner leaves, determined by marking and counting all the outer and inner leaves of the head; and the wet and dry weight of outer and inner leaves, with the leaves being weighed on a precision scale and then being dried in a forced air oven at $65^{\circ} \mathrm{C}$ until constant weight. 
The $\mathrm{N}$ and $\mathrm{Ca}$ contents of the outer and inner leaves were also quantified using four newly mature leaves at the time of head formation from each plot, following the method of Malavolta (1997). To measure commercial production, heads with commercial classification were weighed on a precision scale.

\subsection{Statistical Analysis}

The data were subjected to analysis of variance (F test) for the application schedule, and regression analysis for the calcium nitrate dose. The statistical analyses were performed using the statistical analysis program Sanest (Zonta et al., 1987).

\section{Results and Discussion}

\subsection{Growth Variables and Yield}

Table 1 shows the averages for the application schedule factor on the characteristics of height and head diameter, stem diameter, height ratio and diameter of the head, compactness and relative index of chlorophyll. The characteristics of head height and diameter, stem diameter, head height $\times$ diameter ratio and relative index of chlorophyll did not vary significantly in relation to the timing of the calcium nitrate application.

Table 1. Mean values of head height (HH), head diameter (HC), stem diameter (SD), head height $\times$ head diameter ratio $(\mathrm{HH} / \mathrm{HC})$, head compaction $(\mathrm{HC})$ and relative index of chlorophyll (RIC) due to calcium nitrate application timing. Catalão, GO, Brazil

\begin{tabular}{|c|c|c|c|c|c|c|}
\hline Schedule & $\mathrm{HH}$ & $\mathrm{HC}$ & SD & $\mathrm{HH} / \mathrm{HC}$ & $\mathrm{HC}$ & RIC \\
\hline & \multicolumn{5}{|c|}{ 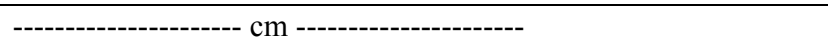 } & ---- Spad ---- \\
\hline $1^{\text {th }}$ Schedule & $14.52 \mathrm{a}$ & $14.61 \mathrm{a}$ & $2.31 \mathrm{a}$ & $1.00 \mathrm{a}$ & $2.21 \mathrm{a}$ & $29.98 \mathrm{a}$ \\
\hline $2^{\text {nd }}$ Schedule & $14.18 \mathrm{a}$ & $14.44 \mathrm{a}$ & $2.30 \mathrm{a}$ & $0.99 \mathrm{a}$ & $1.89 \mathrm{~b}$ & $29.79 \mathrm{a}$ \\
\hline $\mathrm{CV}(\%)$ & 6.40 & 5.95 & 12.64 & 7.71 & 14.72 & 7.07 \\
\hline
\end{tabular}

Note. Means followed by the same letter in the column, for each factor studied, do not differ from one another according to the Tukey test at $5 \%$ probability.

The first application schedule showed significantly better compactness. Compactness also significantly improved as the calcium nitrate dose increased (Figure 1A). American lettuce head compactness is related to the processing yield. Consumers prefer plants with large and heavy heads, which occur in plants with a more compact head and provide higher yield during processing. During processing, more compact heads facilitate leaf chopping, thus increasing the industrial yield (Yuri et al., 2002). 


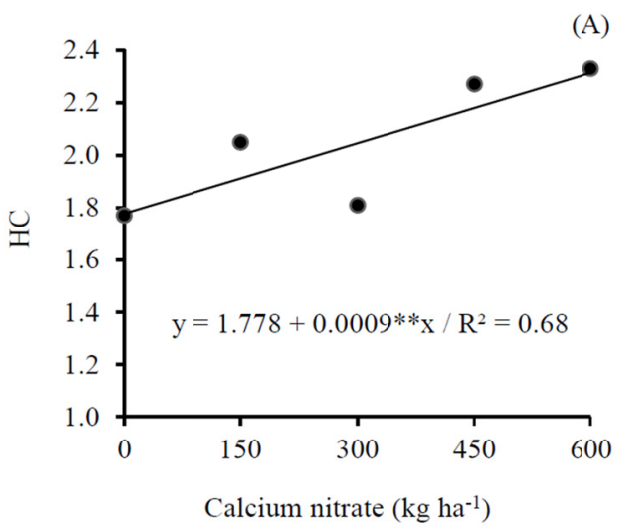

(B)

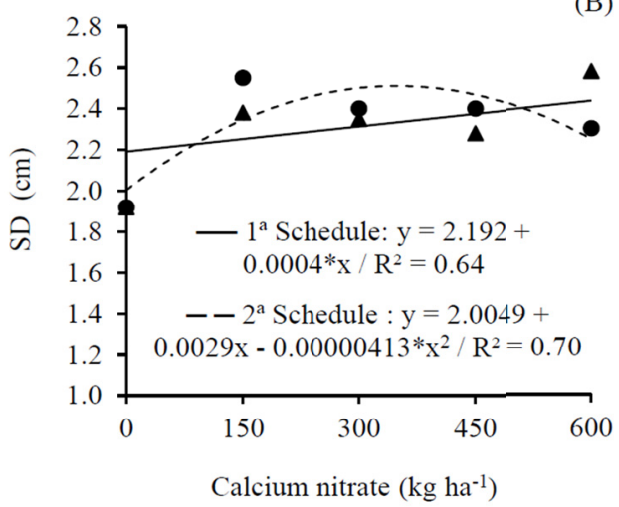

(C)

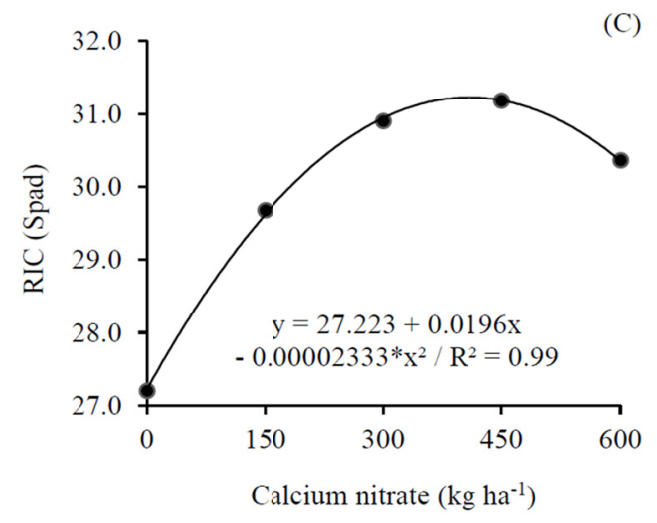

Figure 1. Head compaction (HC) (A), stem diameter (SD) (B) and relative index of chlorophyll (RIC) (C) in function of calcium nitrate application timing and dosage in American lettuce. Catalão, GO, Brazil. *

Significance at $5 \%$ and $* *$ Significance at $1 \%$ probability

Head height, head diameter and head diameter $\times$ height ratio did not vary with calcium nitrate dose. The head height and diameter values were lower than those described by Souza et al. (2013), who found average height values of $16.8 \mathrm{~cm}$ and average diameter values of $16.2 \mathrm{~cm}$ for American lettuce.

For stem diameter, an interaction was observed between the calcium nitrate application schedule and dose, with data fit by quadratic regression for the second application schedule with an estimated maximum at a dose of 351 $\mathrm{kg} \mathrm{ha}^{-1}$. For the first application schedule, the data were fit by an increasing linear regression (Figure 1B). Stem diameter is important to the fast food industry since the stem is manually removed in preparation for subsequent slicing of the lettuce head, thicker stems are removed more quickly, which increases the industrial yield (Mota et al., 2001). In addition, larger stems better support the leaves, which was reflected in the greater compactness observed in the first application schedule.

Calcium nitrate dose affected SPAD chlorophyll content independent of the application schedule, with a quadratic form (Figure 1C). The maximum estimated point for calcium nitrate dosage was $420 \mathrm{~kg} \mathrm{ha}^{-1}$, with a decrease in the index for the highest value used. This result demonstrates that despite higher $\mathrm{N}$ availability, the plant did not get convert it into photosynthetic pigments.

The indirect measurement of chlorophyll serves as a measure of $\mathrm{N}$ in the plant and can be used as a tool to determine $\mathrm{N}$ deficiency. This is possible because $\mathrm{N}$ is related to the formation of the pigment, which is directly related to the photosynthetic potential (Almeida et al., 2011; Taiz \& Zeiger, 2004). Lettuce, as a crop composed mainly of leaves, responds very well to $\mathrm{N}$ fertilization (Resende et al., 2009). In the present study, the SPAD relative index of chlorophyll of 31.18 was higher than that reported by Santos et al. (2010b), who found an average of 22.5 (SPAD) working with compost.

Table 2 shows the number, wet weight and dry weight of the outer and inner leaves for the different calcium nitrate application schedules. The second schedule promoted 10\% higher (mode) inner leaf dry weight, but this was the only significant effect. The modes for both schedules were fit by a quadratic equation model (Figure 2A), with a maximum estimated point of 410 and $444 \mathrm{~kg} \mathrm{ha}^{-1}$ in the first and second schedules, respectively. 
Table 2. Mean values of the number of outer leaves (NOL), number of inner leaves (NIL), outer leaf wet weight (OLWW), outer leaf dry weight (OLDW), inner wet weight (IWW) and inner leaf dry weight (ILDW) as a function of the timing of calcium nitrate application in American lettuce. Catalão, GO, Brazil

\begin{tabular}{|c|c|c|c|c|c|c|}
\hline Schedule & NOL & NIL & OLWW & OLDW & IWW & ILWD \\
\hline & & & \multicolumn{4}{|c|}{ 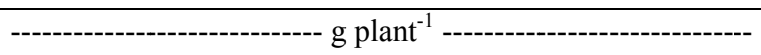 } \\
\hline $1^{\text {th }}$ Schedule & $9.23 \mathrm{a}$ & $12.11 \mathrm{a}$ & $251 \mathrm{a}$ & $4.71 \mathrm{a}$ & $335 \mathrm{a}$ & $5.22 \mathrm{~b}$ \\
\hline $2^{\text {nd }}$ Schedule & $9.11 \mathrm{a}$ & $12.16 \mathrm{a}$ & $267 \mathrm{a}$ & $4.52 \mathrm{a}$ & $342 \mathrm{a}$ & $5.81 \mathrm{a}$ \\
\hline $\mathrm{CV}(\%)$ & 8.31 & 3.84 & 10.89 & 10.07 & 5.49 & 8.82 \\
\hline
\end{tabular}

Note. Means followed by the same letter in the column, for each factor studied, do not differ from one another according to the Tukey test at $5 \%$ probability.

Outer leaf dry weight was fit by an increasing linear regression (Figure 2B), with the increase in the calcium nitrate dose reaching its maximum $\left(5.27 \mathrm{~g} \mathrm{plant}^{-1}\right)$ at the highest calcium nitrate dose, $600 \mathrm{~kg} \mathrm{ha}^{-1}$. This value at the highest dose represents an increase of $24.8 \%$ in relation to the control.

Leaf number did not vary in relation to the calcium nitrate application schedule or dose. Inner leaf wet weight was fitted by a quadratic equation as a function of calcium nitrate dose, with a maximum point estimated at 434 $\mathrm{kg} \mathrm{ha}^{-1}$ as shown in Figure $2 \mathrm{C}$.

This observed response inner leaf wet and dry weight can be attributed to the mobility of N. Because it is mobile within the plant, the $\mathrm{N}$ accumulated in the older leaves and then in the younger leaves, thus promoting greater accumulation of outer leaf dry weight with the increasing calcium nitrate dose. The inner leaf wet and dry weight production can be explained by the plant's distribution of $\mathrm{N}$, as some of the available $\mathrm{N}$ can be used for root growth, hence the decrease after $450 \mathrm{~kg} \mathrm{ha}^{-1}$.
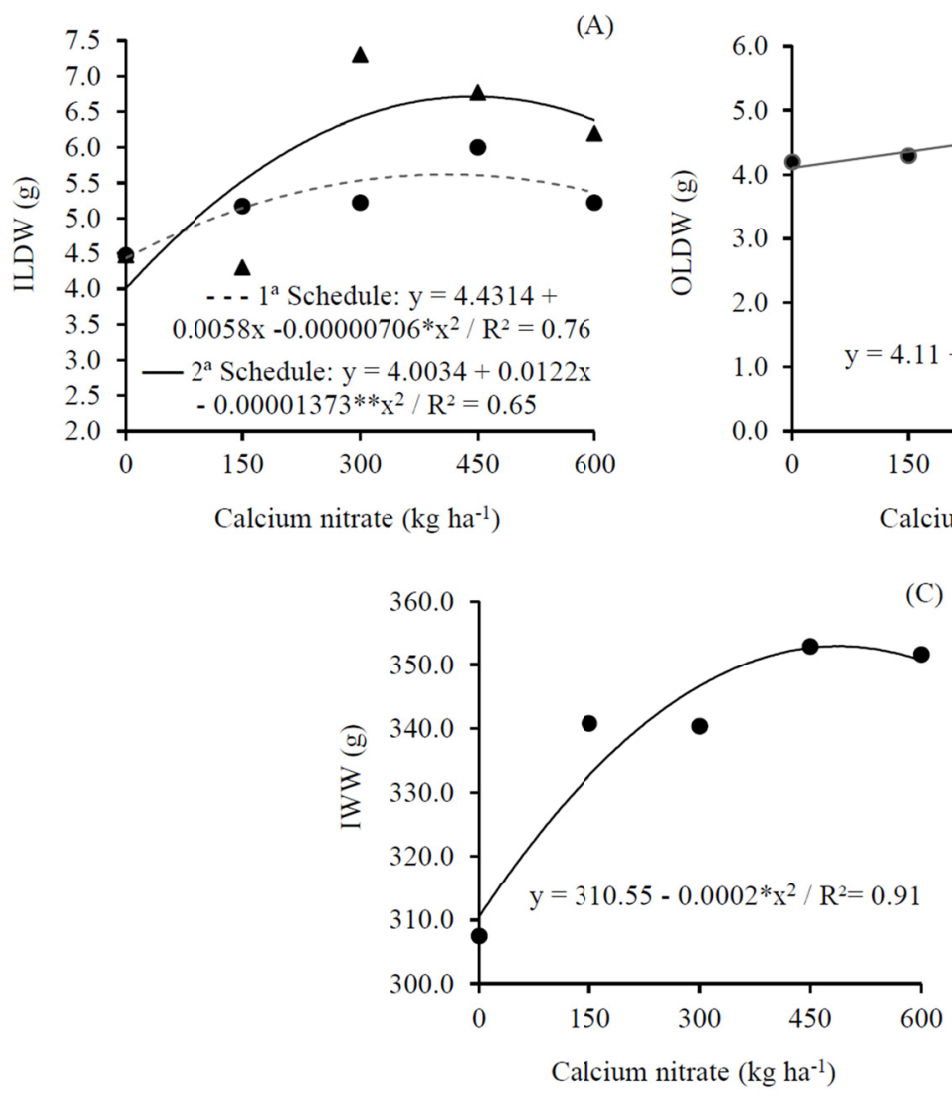

Figure 2. Inner leaf dry weight (ILDW) (A), outer leaf dry weight (OLDW) (B) and inner leaf wet weight (IWW) (C) in American lettuce due to calcium nitrate application timing and dosage. Catalão, GO, Brazil. * Significance at $5 \%$ and $* *$ significance at $1 \%$ probability 
Table 3 shows the $\mathrm{N}$ and $\mathrm{Ca}$ contents of the outer and inner leaves, as well as the commercial production. For the calcium nitrate application schedules, a significant effect was observed on the outer leaf $\mathrm{N}$ and $\mathrm{Ca}$ contents and commercial production when the calcium nitrate was applied as top-dressing (Table 3).

Table 3. Mean values of $\mathrm{N}$ content in outer leaves (NCOL), $\mathrm{N}$ content in inner leaves (NCIL), Ca content in outer leaves (CaCOL), Ca content in inner leaves (CaCIL) and commercial production (CP) as a function of calcium nitrate application timing in American lettuce. Catalão, GO, Brazil

\begin{tabular}{|c|c|c|c|c|c|}
\hline Schedule & NCOL & NCIL & $\mathrm{CaCOL}$ & $\mathrm{CaCIL}$ & $\mathrm{CP}$ \\
\hline & -------. & --------- & $\mathrm{g}^{-1}$ & ------------- & ---- g plant ${ }^{-1}$---- \\
\hline $1^{\text {th }}$ Schedule & $81.61 \mathrm{~b}$ & $79.94 \mathrm{a}$ & $18.74 \mathrm{~b}$ & $19.13 \mathrm{a}$ & $320 \mathrm{~b}$ \\
\hline $2^{\text {nd }}$ Schedule & $83.99 \mathrm{a}$ & $79.58 \mathrm{a}$ & $20.06 \mathrm{a}$ & $20.65 \mathrm{a}$ & $336 \mathrm{a}$ \\
\hline $\mathrm{CV}(\%)$ & 2.52 & 5.60 & 9.13 & 13.53 & 6.52 \\
\hline
\end{tabular}

Note. Means followed by the same letter in the column, for each factor studied, do not differ from one another according to the Tukey test at $5 \%$ probability.

A significant interaction was observed for the inner leaf $\mathrm{N}$ content as a function of the application schedule (Figure 3A). The values for application at planting and as top-dressing were fit by a quadratic regression with maximum points of 396 and $398 \mathrm{~kg} \mathrm{ha}^{-1}$, respectively. According to Grangeiro et al. (2006), the period of higher $\mathrm{N}$ demand for lettuce is from 22 to 27 days after transplanting (DAT) and for Ca from 17 to 22 DAT. In a study involving $\mathrm{N}$ fertilization in lettuce plants, Pôrto et al. (2008) found a linear increase in foliar N content. Due to the $\mathrm{N}$ uptake flow and its high nutritional requirements, the behaviour of $\mathrm{N}$ in the soil and climatic conditions, $\mathrm{N}$ fertilization is needed at two or three points to increase the nutrient efficiency of the soil-plant system (Grespan \& Zancanaro, 1999).
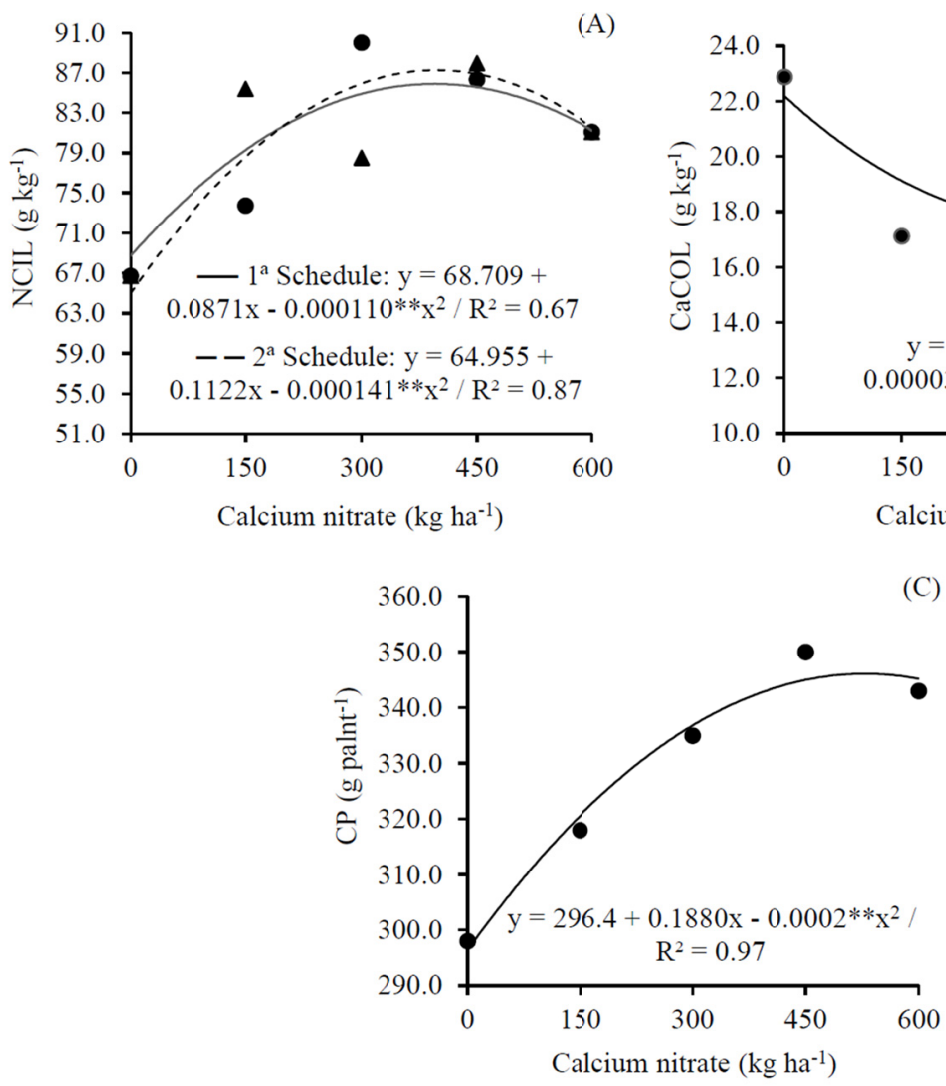

(B)

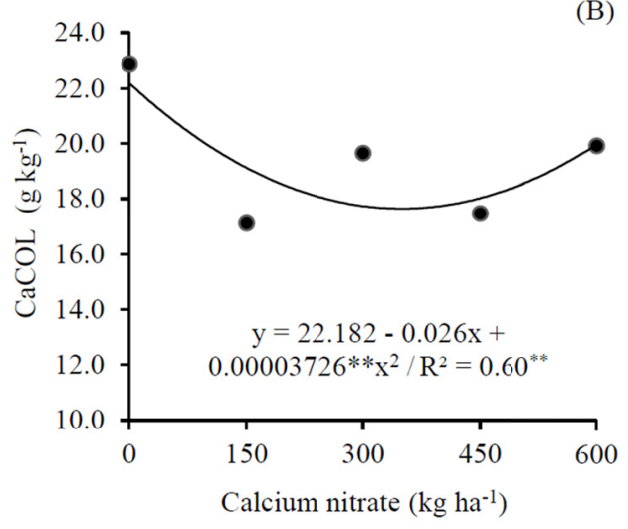

(C)

Figure 3. $\mathrm{N}$ content in the inner leaves (NCIL) (A) Ca content in the outer leaves (CaCOL) (B) and commercial production $(\mathrm{CP})(\mathrm{C})$ due to calcium nitrate application timing and dosage in American lettuce. Catalão, GO, Brazil. ** Significance at $1 \%$ probability 
The values of $\mathrm{Ca}$ in the outer leaves were fitted by a quadratic regression with a minimum point of $348 \mathrm{~kg} \mathrm{ha}^{-1}$ (Figure 3B). This can be explained by the increase in wet weight; the cells became more turgid, thus increasing the internal water content and diluting the $\mathrm{Ca}$.

$\mathrm{N}$ is a mobile element in the plant, being important mainly in the synthesis of pigments and amino acids. Ca, however, is a practically immobile element in the plant, being found mainly in regions that are in full vegetative growth (Tsialtas et al., 2016). Due to these mobility characteristics, top-dressing fertilization provided higher leaf contents, allowing better absorption, due to the more developed root system and, consequently, adequate mobilization of the nutrients by the plant (Maillard et al., 2015).

In commercial production, the observed increase may be related to the application of calcium nitrate when the root system is more developed, taking advantage of the N. According to Melgar et al. (1991), the N availability can be increased through split application during the growth period of the plants since this parcelling improves $\mathrm{N}$ absorption by the plants and reduces losses from leaching because the plant root system is more developed. Cortez et al. (2009) evaluated lettuce production as a function of fertilization with calcium nitrate in a nutrient solution and concluded that increasing the doses provided better production. The mean values for the variable were similar to but lower than those observed by Resende et al. $(2005,2009)$, who used higher doses of N per $\mathrm{ha}^{-1}$.

When commercial production was evaluated with the application of calcium nitrate, a significant effect was observed for the doses, with data being fitted to a quadratic linear regression with a maximum point of $470 \mathrm{~kg}$ $\mathrm{ha}^{-1}$ (Figure 3C). According to Nascimento et al. (2017), different sources of $\mathrm{N}$ can be used for crisp lettuce at the discretion of the producer according to cost. Silva et al. (2017) observed an increase in the production of carrots with the use of calcium nitrate. $\mathrm{N}$ in the form of nitrate is available immediately for absorption and is readily metabolizable by the plant. Urea, for example, requires approximately 25 days to make $\mathrm{N}$ available (Rogeri et al., 2015). Calcium nitrate is commonly used as top-dressing to supply both $\mathrm{N}$ and Ca requirements (Filgueira, 2013).

\section{Conclusions}

The application of calcium nitrate positively influenced the nutritional characteristics of American lettuce in the $2^{\text {nd }}$ schedule and the dose of $470 \mathrm{~kg} \mathrm{ha}^{-1}$ presented better production.

\section{Acknowledgements}

To the State University of Goiás (Universidade Estadual de Goiás) (UEG), Campus Ipameri, for the support in the conduction of the project, for the scholarship granted to the first author and for the productivity bag PROBIP to the fourth author and the Group of Study and Research in Plant Science (GEPFi). To the Goiano Federal Institute (Instituto Federal Goiano) (IF Goiano), Campus Urutaí for financial support.

\section{References}

Almeida, T. B. F., Prado R. M., Corrêa, M. A. R., Puga, A. P., \& Barbosa, J. C. (2011). Avaliação nutricional da alface cultivada em soluções nutritivas suprimidas de macronutrientes. Revista Biotemas, 24(1), 27-36. https://doi.org/10.5007/2175-7925.2011v24n2p27

Beninni, E. R. Y., Takahashi, H. W., \& Neves, C. S. V. J. (2003). Manejo do cálcio em alface de cultivo hidropônico. Horticultura Brasileira, 21(4), 605-610. https://doi.org/10.1590/S0102-053620030004 00005

Cardoso, A. I. I., \& Hiraki, H. (2001). Avaliação de doses e épocas de aplicação de nitrato de cálcio em cobertura na cultura do rabanete. Horticultura Brasileira, 19(3), 196-199. https://doi.org/10.1590/S0102-053620010 00300007

Cardoso, M. R. D., Marcuzzo, F. F. N., \& Barros, J. R. (2014). Classificação climática de Köppen-Geiger para o Estado de Goiás e o Distrito Federal. ACTA Geográfica, 8(16), 40-55. https://doi.org/10.5654/acta. v8i16.1384

Chohura, P., \& Kołota, E. (2011). Effect of differentiated nitrogen fertilization on the yield and quality of leaf lettuce. Folia Horticulturae, 23(1), 61-66. https://doi.org/10.2478/v10245-011-0010-9

Collier, G. F., \& Tibbitts, T. W. (1982). Tip burn of lettuce. Horticultural Reviews, 4, 49-65.

Cometti, N. N., Matias, G. C. S., Zonta, E., Mary, W., \& Fernandes, M. S. (2004). Compostos nitrogenados e açúcares solúveis em tecidos de alface orgânica, hidropônica e convencional. Horticultura Brasileira, 22(4), 748-753. https://doi.org/10.1590/S0102-05362004000400016

Cortez, J. W., Bonilha, M. A. F. M., \& Teixeira, A. N. S. (2009). Efeito de diferentes níveis de nitrato de cálcio 
em alface no sistema hidropônico. Nucleus, 6(1), 263-270. https://doi.org/10.3738/nucleus.v6i1.158

Costa, K. A. P., Faquin, V., \& Oliveira, I. P. (2010). Doses e fontes de nitrogênio na recuperação de pastagens de capim-marandu. Arquivo Brasileiro de Medicina Veterinária e Zootecnia, 62(1), 192-199. https://doi.org/ 10.1590/S0102-09352010000100026

Filgueira, F. A. R. (2013). Novo manual de olericultura: Agrotecnologia moderna na produção e comercialização de hortaliças (p. 421). Viçosa: Editora UFV.

Grangeiro, L. C., Costa, K. R., Medeiros, M. A., Salviano, A. M., Negreiros, M. Z., Neto, F. B., \& Oliveira, S. L. (2006). Acúmulo de nutrientes por três cultivares de alface cultivadas em condições do Semi-Árido. Horticultura Brasileira, 24(2), 190-194. https://doi.org/10.1590/S0102-05362006000200013

Grespan, S. L., \& Zancanaro, L. (1999). Nutrição e adubação do algodoeiro no Mato Grosso. In M. T. Fundação (Ed.), Mato Grosso: Liderança e Competividade (pp. 87-99). Rondonópolis: Fundação MT.

Maillard, A., Diquélou, S., Billard, V., Laîné, P., Garnica, M., Prudent, M., \& Ourry, A. (2015). Leaf mineral nutrient remobilization during leaf senescence and modulation by nutrient deficiency. Frontiers in Plant Science, 6(317), 1-15. https://doi.org/10.3389/fpls.2015.00317

Malavolta, E., Vitti, G. C., \& Oliveira, A. S. (1997). Avaliação do estado nutricional das plantas: Princípios e aplicações (2nd ed., p. 319). Piracicaba: Potafos.

Martinez, L. M., Velasc, O. V., Arturo, V. V., Luna, R. R., Valle, J. R. E., Angeles, G. V. C., \& Lugo, M. L. M. (2013). Effect of calcium nitrate and substrates on tomato yield. Revista Mexicana de Ciências Agrícolas, 6(Extra), 1175-1184.

Melgar, R. J., Smyth, T. J., Cravo, M. S., \& Sánches, P. A. (1991). As doses e épocas de aplicação de fertilizantes nitrogenados para milho em latossolo da Amazônia Central. Revista Brasileira de Ciência do Solo, 15(3), 289-296.

Mota, J. H., Souza, R. J., Silva, E. C., Carvalho, J. G., \& Yuri, E. (2001). Efeito do cloreto de potássio via fertirrigação na produção de alface-americana em cultivo protegido. Ciência e Agrotecnologia, 25(3), 542-549.

Nascimento, M. V., Silva Junior, R. L., Fernandes, L. R., Xavier, R. C., Benett, K. S. S., Seleguini, A., \& Benett, C. G. S. (2017). Manejo da adubação nitrogenada nas culturas de alface, repolho e salsa. Revista de Agricultura Neotropical, 4(1), 65-71.

Olfati, J. A., Peyvast, G. H., Nosratie-Rad, Z., Saligedar, F., \& Rezaei, F. (2009). Application of municipal solid wast composton lettuce yield. International Journal of Vegetable Science, 15(2), 168-172. https://doi.org/ $10.1080 / 19315260802572032$

Pôrto, M. L., Alves, J. C., Souza, A. P., Araújo, R. C., \& Arruda, J. A. (2008). Nitrate production and accumulation in lettuce as affected by mineral Nitrogen supply and organic fertilization. Horticultura Brasileira, 26(2), 227-230. https://doi.org/10.1590/S0102-05362008000200019

Resende, G. M., Alvarenga, M. A. R., Yure, J. E., Souza, R. J., Mota, J. H., Carvalho, J. G., \& Rodrigues Júnior, J. G. (2005). Produtividade e qualidade pós-colheita da alface americana em função das doses de nitrogênio e molibdênio. Horticultura Brasileira, 23(4), 976-981. https://doi.org/10.1590/S0102-05362005000400023

Resende, G. M., Alvarenga, M. A. R., Yure, J. E., Souza, R. J., Mota, J. H., Carvalho, J. G., \& Rodrigues Júnior, J. G. (2009). Rendimento e teores de macronutrientes em alface americana em função das doses de nitrogênio e molibdênio em cultivo de verão. Ciência \& Agrotecnologia, 33(1), 153-163. https://doi.org/ 10.1590/S1413-70542009000100022

Rogeri, D. A., Ernani, P. R., Lourenço, K. S., Cassol, P. C., \& Gatiboni, L. C. (2015). Mineralização e nitrificação do nitrogênio proveniente da cama de aves aplicada ao solo. Revista Brasileira de Engenharia Agrícola e Ambiental, 19(6), 534-540. https://doi.org/10.1590/1807-1929/agriambi.v19n6p534-540

Santi, A., Scaramuzza, W. L. M. P., Neuhaus, A., Dallacort, R., Krause, W., \& Tieppo, R. C. (2013). Desempenho agronômico de alface americana fertilizada com torta de filtro em ambiente protegido. Horticultura Brasileira, 31(2), 338-343. https://doi.org/10.1590/S0102-05362013000200027

Santos, C. M., Gonçalves, E. R., Endres, L., Gomes, T. C. A., Jadoski, C. J., \& Nascimento, L. A. (2010a). Atividade Fotossintética em alface (Lactuca sativa L.) submetidas a diferentes compostagens de resíduos industriais. Pesquisa Aplicada \& Agrotecnologia, 3(3), 95-112. 
Santos, H. G., Jacomine, P. K. T., Anjos, L. H. C., Oliveira, V. A., Lumbreras, J. F., Coelho, M. R., ... Oliveira, J. B. (2013). Sistema brasileiro de classificação de solos (3rd ed., p. 353). Brasília-DF: Embrapa, Centro Nacional de Pesquisa de Solos.

Santos, M. M., Galvao, J. C. C., Silva, I. R., Miranda, G. V., \& Finger, F. L. (2010b). Épocas de aplicação de nitrogênio em cobertura e na cultura do milho em plantio direto, e alocação do nitrogênio (15n) na planta. Revista Brasileira de Ciência do Solo, 34(4), 1185-1194. https://doi.org/10.1590/S0100-06832010000 400018

Silva, L. M., Basílio, S. A., Silva Júnior, R. L., Benett, K. S. S., \& Benett, C. G. S. (2017). Aplicação de nitrogênio, potássio e cálcio na cultura da cenoura. Revista de Agricultura Neotropical, 4(3), 69-76.

Souza, A. L., Seabra Junior, S., Diamante, M. S., Souza, L. H. C., \& Nunes, M. C. M. (2013). Comportamento de cultivares de alface americana sob clima tropical. Revista Caatinga, 26(4), 123-129.

Souza, D. M. G., \& Lobato, E. (2004). Correção do solo e adubação (2nd ed., p. 416). Brasília: Embrapa Cerrados.

Taiz, L., \& Zaiger, E. (2004). Plant physiology (3rd ed., p. 690). Sunderland: Sinauer Associates.

Tsialtas, J. T., Shabala, S., \& Matsi, T. (2016). A prominent role for leaf calcium as a yield and quality determinant in upland cotton (Gossypium hirsutum L.) varieties grown under irrigated mediterranean conditions. Journal of Agronomy and Crop Science, 202(3), 161-173. https://doi.org/10.1111/jac.12126

Yuri, J. E., Souza, R. J., Freitas, S. A. C., Rodrigues Júnior, J. C., \& Mota, J. H. (2002). Comportamento de cultivares de alface tipo americana em Boa Esperança. Horticultura Brasileira, 20(2), 229-232. https://doi.org/10.1590/S0102-05362002000200023

Zanão Júnior, L. A., Lana, R. M. Q., \& Sá, K. A. (2005). Formas de parcelamento e fontes de adubação nitrogenada para a produção de couve-da-Malásia. Horticultura Brasileira, 23(4), 965-969. https://doi.org/ $10.1590 / \mathrm{S} 0102-05362005000400021$

Zonta, E. P., Machado, A. A., \& Silveira Júnior, P. (1987). Sistema de análise estatística para microcomputadores: Manual de utilização (2nd ed., p. 138). Pelotas-RS: DMEC/IFM/UFPel.

\section{Copyrights}

Copyright for this article is retained by the author(s), with first publication rights granted to the journal.

This is an open-access article distributed under the terms and conditions of the Creative Commons Attribution license (http://creativecommons.org/licenses/by/4.0/). 